\title{
Finansal Okuryazarlık Düzeyi ile Sosyal Ağların Etkileşimi Üzerine Ampirik Bir Uygulama
}

\author{
Özlem Ergüta,Ceren Camkıran ${ }^{\mathrm{b}, \mathrm{c}}$, A. Mete Çilingirtürk ${ }^{\mathrm{d}}$
}

\section{Özet}

Finansal okuryazarlık, belirsizliğin arttığ verebilmelerini, finansal durumları hakkında bilinçli bir yol izleyebilmelerini sağlayan önemli bir kavram olarak güncelliğini korumaktadır. Bu konuda bilincin oluşturulması, bu bilincin doğru finansal davranışlara yönlendirilmesi açısından önemlidir. Bu çalışmada amaç, kişilerin finansal okuryazarlık konusundaki bilgi düzeylerinden yola çıkarak finansal tutum ve davranışlarını incelemek, sosyal medya ve yazılım uygulamalarının finansal okuryazarlık üzerinde etkili olup olmadığını araştırmaktır. Bu amaçla 225 kişiyle e-posta yoluyla anket gerçekleştirilerek elde edilen veri setine karar ağaçları ve lojistik regresyon analizi uygulanmıştır. Karar Ağaçları sonuçlarına göre, sınıflamada en etkili değişkenin yaş olduğu belirlenerek veri seti, yaşı 25 yaş ve altı ile 25 yaş üstü olmak üzere iki gruba ayrılmıştır. Lojistik regresyon analizi sonuçlarına göre, finansal okuryazarlıkla ilgili temel bilgi düzeyini etkileyen değiş̧kenler 25 yaş üstü için cinsiyet, eğitim ve sosyal ağ skoru iken 25 yaş ve altı için sadece finansal tutum skorlarıdır.

\section{Anahtar Kelimeler}

Finansal Okuryazarlık

Sosyal Medya

Lojistik Regresyon

Karar Ağacı

Makale Hakkında

Geliş Tarihi: 21.10.2019

Kabul Tarihi: 24.04.2020

Doi: $10.18026 /$ cbayarsos.635429

\section{An Empirical Application on the Interaction of Financial Literacy Level with Social Networks}

\begin{abstract}
Financial literacy remains an up-to-date concept as it enables individuals to make rational decisions, to facilitate decision-making processes and to follow an informed path about their financial situation in an environment of uncertainty. Establishing awareness about financial literacy is important for directing this awareness towards correct financial behaviors. The aim of this study is to investigate financial attitudes and behaviors of individuals based on their level of knowledge about financial literacy and to investigate whether social media and software applications affect financial literacy. For this purpose, decision trees and logistic regression analysis were applied to the data set obtained by creating a sample of the study by e-mail survey application to 225 people. According to the results of decision trees and logistic regression analysis, the variables affecting the basic level of knowledge about financial literacy are gender, education and social network score for the age above 25 , and financial attitude scores for the age of 25 and younger.
\end{abstract}

Keywords

\author{
Financial Literacy \\ Social Media \\ Logistic Regression \\ Decision Tree
}

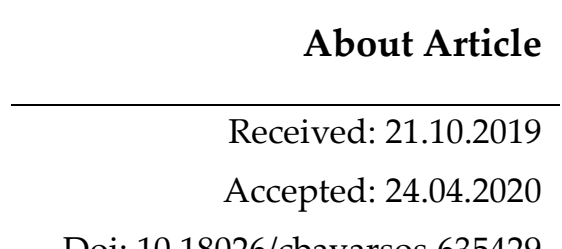

Doi: 10.18026/cbayarsos.635429

\footnotetext{
a Dr. Öğr. Üy., Marmara Üniversitesi, İktisat Fakültesi, Ekonometri Bölümü, mail: ozlem.ergut@marmara.edu.tr, ORCID: 0000-0002-4076-8343

b İletişim Yazarı: ceren.camkiran@marmara.edu.tr

c Arş. Gör., Marmara Üniversitesi, İktisat Fakültesi, Ekonometri Bölümü, mail: ceren.camkiran@marmara.edu.tr, ORCID: 0000-0001-8675-5890

d Prof. Dr., Marmara Üniversitesi, İktisat Fakültesi, Ekonometri Bölümü, mail: acilingi@marmara.edu.tr, ORCID: 0000-0001-8677-7969
} 


\section{Giriş}

Pek çok farklı tanımı olmakla birlikte finansal okuryazarlık OECD INFE (International Network on Financial Education- Uluslararası Finansal Eğitim A $\breve{g} 1$ ) tarafından finansal kararların doğru verilebilmesi ve bireysel olarak finansal bir refah düzeyine erişebilmek için gerekli finansal farkındalık, bilgi, beceri, tutum ve davranışların tümü olarak tanımlanmaktadır (OECD INFE, 2011). Finansal okuryazarlık, risk azaltıcı stratejiler belirleyerek ve finansal ürünleri en etkin şekilde makul kararlar almada etkin kullanarak, tüketicilerin zor zamanlara hazırlanmalarına yardımcı olur (Wachira ve Kihiu, 2012).

Rekabetin yoğun olarak yaşandığı küreselleşen dünyada finansal ürün çeşitliliği artmış, karmaşık bir finansal ortamda faaliyet gösteren firmalar ve kişiler için finansal okuryazarlık temel bir beceri haline gelmiştir. Finansal ihtiyaçların yönetilmesi, finansal sorunlara yönelik olarak çözümlerin bulunabilmesi ve geleceğin planlanması için kişilerin finansal okuryazarlık ile ilgili yeterli düzeyde bilgiye ve bilince sahip olmaları gerekmektedir. Bu nedenle hemen hemen her ülkede finansal okuryazarlık seviyesinin arttırılması için çeşitli stratejiler oluşturulmakta; finansal eğitimin sağlanması için öğrenme fırsatları yaratılmaktadır. Türkiye'de TCMB (Türkiye Cumhuriyet Merkez Bankası) finansal okuryazarlık ve ekonomi eğitimi çalışmaları kapsamında farklı hedef kitlelere ulaşmayı amaçlamış, bu amaç doğrultusunda bilgi ve farkındalık seviyesini yükseltmek için farklı yaş gruplarına yönelik çeşitli faaliyet ve etkinlikler düzenlemiştir.

Finansal Okuryazarlık ve Erişim Derneği (FODER) tarafından 26 ilde 2.000 kişi ile yapılan Türkiye Finansal Okuryazarlık Araştırması sonucuna göre Türkiye'de minimum finansal bilgiye sahip olan bireylerin oranı \%70 iken; finansal bilgi düzeyi, çalışma hayatında olan, gelir düzeyi yüksek ve eğitimli bireylerde daha yüksek olduğu tespit edilmiştir (FODER, 2017).

Finansal okuryazarlığı olan bireyler temel finansal konular hakkında bilgiye sahiptirler ve karar alırken daha rasyonel olmaktadırlar. Finansal okuryazarlık, bireyleri bütçeleri oluşturmak, tasarruf planları başlatmak ve stratejik yatırım kararları almak için gerekli finansal bilgilerle aşılamaya yardımcı olmaktadır (Greenspan, 2002).

Finansal okuryazarlıkla beraber gelişen finansal tutum ve davranışlar; alınan yatırım kararları, gelecekle ilgili yapılan bütün maddi planlamalar da dikkat çeken konular arasına girmiştir (Karyağdı, 2018).

Finansal okuryazarlık konusunda kayda değer bilgi düzeyinin oluşturulması bunun doğru finansal davranışlara yönlendirmesi açısından önem arz etmektedir. Çünkü kişinin davranışlarının finansal refahı üzerine önemli bir etkisi vardır. Tutumlar ve tercihler de finansal okuryazarlığın önemli bir unsuru olarak kabul edilir. Örneğin, insanlar gelecekleri için tasarruf konusunda oldukça olumsuz bir tavır sergiliyorsa, bu tür davranışlarda bulunmaya daha az yatkın olacakları iddia edilmektedir. Benzer şekilde, kısa vadeli talepleri önceliklendirmeyi tercih ediyorlarsa, o zaman kendilerini acil durum tasarrufları sağlamaları veya daha uzun vadeli finansal planlar yapmaları pek mümkün değildir (Atkinson ve Messy, 2012).

$\mathrm{Bu}$ çalışmada amaç kişilerin finansal okuryazarlık konusundaki bilgi düzeylerini belirleyip, sosyal medya uygulamalarının finansal okuryazarlık üzerindeki etkisini ortaya koymaktır. Belirlenen amaç doğrultusunda karar ağaçları ve lojistik regresyon analizinden yararlanılmıştır. 


\section{Literatür Taraması}

Literatür incelendiğinde yapılan çalışmaların iki grupta toplandığı görülmüştür. Birinci gruptaki çalışmalar finansal okuryazarlık düzeyinin belirlenmesine yönelik çalışmalardan oluşuyorken; diğer grup ise finansal okur yazarlık ile kredi kartı kullanımı, tasarruf, bireysel bütçeleme davranışları üzerindeki etkisini araştıran çalışmalardır.

Birinci grupta yapılan çalışmaların bazıları şöyledir:

Alkaya ve Yağlı (2015) çalışmalarında, öğrencilerin finansal okuryazarlık, finansal bilgi, tutum ve davranışlarını araştırmışlardır. Sonucunda, finansal tutum ile finansal davranış arasında istatistiksel olarak anlamlı bir ilişki olduğu bulunmuştur. Ancak öğrencilerin finansal bilgi bakımından yeterli seviyeye sahip olmadıkları sonucuna ulaşılmıştır.

Biçer ve Altan (2016), finansal okuryazarlık düzeylerini dört boyutta incelemek amacıyla bir fakültede 335 öğrenci ile anket çalışması gerçekleştirmişlerdir. Finansal eğitim alan öğrencilerin finansal okuryazarlık algılarının diğerlerine göre daha yüksek olduğu sonucuna ulaşmışlardır.

Danışman, Sezer ve Gümüş (2016), İktisadi ve İdari Bilimler öğrencilerinin finansal okuryazarlık düzeyini belirlemek için anket çalışması uygulamışlar, cinsiyet ve sınıf durumu ile finansal okuryazarlık düzeyi arasında ilişki bulamamışlardır.

Çetiner ve Çilingirtürk (2019), çevrimiçi internet kullanıcılarından toplanan anket verisi ile finansal okuryazarlık ile sosyal medya ilişkisini incelemişler, eğitimin en önemli etken olduğunu ancak bunun da finansal okuryazarlık tutumlarına bağlı olduğunu belirlemişlerdir.

İkinci grup çalışmalara ise şunlar örnek gösterilebilir:

Barış (2016), öğrencilerin finansal okuryazarlık seviyelerinin bütçeleme davranışları üzerinde etkisi olup olmadığını tespit etmek amacıyla gerçekleştirdiği anket çalışması sonucunda öğrencilerin temel düzey finansal okuryazarlıklarının düşük olmadığını, ancak ileri düzey finansal okuryazarlıklarının düşük olduğunu belirtmiştir.

Barış ve Şahin (2017), kamu çalışanlarının finansal okuryazarlık seviyelerinin tasarrufları üzerinde bir etkisi olup olmadığını belirlemek amacıyla bir çalışma gerçekleştirmişlerdir. Çalışma sonucunda, yaş ve hane halkı geliri gibi demografik değişkenler anlamlı bulunmuştur. Aynı zamanda finansal gelişmeleri takip etme ve finansal okuryazarlık durumunun tasarrufları üzerinde anlamlı bir etkiye sahip olduğu sonucuna ulaşılmıştır.

Bayar, Sezgin ve Öztürk (2017), Uşak Üniversitesi personelinin finansal okuryazarlığın kişisel tasarruf üzerindeki etkisini ölçmek amacıyla lojistik regresyon analizini uygulamışlar ve finansal okuryazarlık, gelir düzeyi, yaş ve eğitim düzeyinin kişisel tasarrufları olumlu yönde etkilediğini saptamışlardır.

Çinko ve ark.(2017), Marmara Üniversitesi'nin çeşitli fakültelerinde kayıtlı öğrencilerin finansal okuryazarlık düzeylerinin, finansal bilgi, davranış ve tutum boyutunda, tespit etmek amacıyla gerçekleştirdikleri çalışmada, finansal bilgi, davranış ve tutum düzeylerinin cinsiyet, fakülte, sınıf, konaklama türü ve gelire göre farklılaştı̆̆ını tespit etmişlerdir.

Durmuşkaya ve Kavas (2018), Türkiye'deki akademisyenlerin finansal okuryazarlık düzeylerini ölçmek amacıyla 415 akademisyenle gerçekleştirdikleri anket çalışması sonucunda erkek akademisyenlerin kadınlardan, sosyal bilimler alanında çalışan 
akademisyenlerin sağlık bilimlerinde çalışanlardan finansal açıdan daha okuryazar olduğu sonucuna ulaşmışlardır.

\section{Araştırmanın Amacı ve Kapsamı}

Bu çalışmanın amacı kişilerin finansal okuryazarlık konusundaki bilgi düzeylerini, tutum ve davranışlarını araştırarak, sosyal medya ve yazılım uygulamalarının finansal okuryazarlık üzerindeki etkisini belirlemektir. Verilerin toplanmasında e-posta yoluyla anket tekniği uygulanmış, farklı ekonomik ve sosyal yapıdaki internet kullanıcısı olan ve ulaşılabilen toplam 225 birey araştırmanın örneklemini oluşturmuştur (Çetiner ve Çilingirtürk, 2019). Anket 4 bölümden meydana gelmektedir. İlk bölümdeki sorular Kılıç, Ata ve Seyrek (2015)' in çalışmasında yer alan, kişilerin genel ekonomi ve finans konusundaki bilgi düzeyini ölçmek amacıyla "Doğru", "Yanlış" ve "Fikrim Yok" cevap seçenekleri ile sorulan 8 soru kullanılarak oluşturulmuştur. İkinci bölümde kişilerin finansal davranış ve tutumları Sarıgül (2015) tarafından geliştirilen "Finansal Okuryazarlık Tutum ve Davranış Ölçeği" ile belirlenen ve 14 sorudan oluşan nihai ölçek soruları kullanılarak ölçülmeye çalışılmıştır. Üçüncü bölümünde kişilerin, finansal okuryazarlık durumları ile sosyal ağ kullanımları arasındaki ilişkiyi ortaya koymak amacıyla 20 soru hazırlanmıştır. Anketin son bölümde ise demografik sorular yer almaktadır. Belirlenen amaç doğrultusunda verilerin analizinde karar ağaçları ve lojistik regresyon analizinden yararlanılmıştır.

\section{Metodoloji}

Analiz yöntemi iki aşamadan oluşmaktadır. Bunun öncelikli sebebi bütün örneklem katmanlarını tek bir modelle açıklamanın jenerasyon farklılığı nedeniyle yanlış olduğunun düşünülmesi ve bu yönde bulgular elde edilmesidir. İlişki yapıları incelendiğinde parametrik olmayan yöntemlerin kullanılabileceği kırılma veya eğim farklılıklarından ziyade yapı farklılığı gözlendiğinden öncelikle karar ağaçları ile temel ayırımlar belirlenmiş, arkasından elde edilen iki gurup lojistik regresyon ile modellenmiştir.

\section{Lojistik Regresyon Analizi}

Neden sonuç ilişkisini ortaya koymak amacıyla bağımlı ve bağımsız değişken ayırımının yapıldığı çalışmalarda bağımlı değişkenin kategorik bir değişken olması durumunda En Küçük Kareler yöntemiyle yapılan tahminler yetersiz kalmaktadır. Bağımlı değişkenin olumlu- olumsuz, iyi-orta-kötü gibi iki ya da çok düzeyli kategorik verilerden oluşması durumunda neden-sonuç ilişkisinin incelenmesinde lojistik regresyon analizinden yararlanılmaktadır.

$\mathrm{Bu}$ yöntemin çoğunlukla tercih edilmesinde, bağımlı değişkenin iki ya da daha çok düzey içeren kesikli bir değişken olması durumunda da kullanılabilir olmasının yanı sıra, matematiksel olarak esnekliği ve kolay yorumlanabilirliği etkilidir (Tatlıdil, 2002).

Lojistik regresyon analizinde bağımlı değişkenin iki kategoriden (hasta-sağlam, başarılıbaşarısız) oluşması durumunda ikili(binary) lojistik regresyon; bağımlı değişken ikiden çok düzeyli olması durumunda çoklu (multinomial) lojistik regresyon; bağımlı değişkenin sıralı nitel veri tipinde (hafif-orta-şiddetli) olması durumunda ise sıralı lojistik regresyon modeli tercih edilmektedir.v 
Bağımlı değişkenin sürekli değişken olduğu klasik regresyon analizinde, hata teriminin normal dağıldığı varsayılırken, bağımlı değişkenin nitel bir değişken olması durumunda bu varsayım yerine getirilememektedir. Bağımlı değişkenin nitel bir değişken olması durumunda kullanılabilecek yöntemlerden biri olan lojistik regresyon modeli aşağıdaki gibi tanımlanmaktadır:

$$
L_{i}=\ln \left(\frac{P_{i}}{1-P_{i}}\right)=\ln \left(e^{Z_{i}}\right)=Z_{i}=\beta_{0}+\beta_{1} X_{i}
$$

Burada $P_{i}$ bir olayın gerçekleme olasılığı, $\left(1-P_{i}\right)$ gerçekleşmeme ihtimalini göstermek üzere şöyle hesaplanmaktadır:

$$
\begin{gathered}
P_{i}=\frac{1}{1+e^{-Z_{i}}}=\frac{1}{1+e^{-\left(\beta_{0}+\beta_{1} X_{i}\right)}} \\
1-P_{i}=\frac{1}{1+e^{Z_{i}}}
\end{gathered}
$$

Eşitliklerden de görülebileceği gibi ile arasındaki ilişki doğrusal değildir. Olayın gerçekleşme olasılığının gerçekleşmeme olasılığına oranlanmasıyla bulunan değere fark oranı (odds oranı) veya bahis oranı denilmektedir.

$$
\frac{P_{i}}{1-P_{i}}=\frac{\left(1 / 1+e^{-Z_{i}}\right)}{\left(1 / 1+e^{Z_{i}}\right)}=e^{Z_{i}}
$$

Fark oranının logaritması L, sadece bağımsız değişkene göre değil aynı zamanda anakütle katsayılarına göre de doğrusaldır. Eşitlikte belirtilen L, logit olarak adlandırılmakta ve lojistik regresyon denkleminin sol tarafını oluşturmaktadır.

Lojistik regresyon modelinin parametrelerini tahmin etmek için kullanılan yöntemlerden biri en çok olabilirlik yöntemidir. Bu yöntemin uygulanmasındaki ilk adım, gözlenen verinin olasılığını bilinmeyen parametrelerin bir fonksiyonu olarak ifade eden olabilirlik fonksiyonunun oluşturulmasıdır. Parametrelerin en çok olabilirlik tahmin edicileri bu fonksiyonun maksimum yapacak değerler olarak seçilmekte böylece elde edilen tahminciler ile gözlenen verilere en yakın tahminler bulunmaktadır (Hosmer vd., 2013).

En çok olabilirlik yöntemiyle model katsayılarının tahmin edilmesi sonrasında katsayıların anlamlılığının incelenmesinde Wald istatistiğinden yararlanılmaktadır. Wald test istatistiği:

$$
W_{i}=\hat{\beta}_{i} / s\left(\hat{\beta}_{i}\right)
$$

şeklinde hesaplanmaktadır.

Wald test istatistiği, parametrenin en çok olabilirlik tahmininin $\left(\hat{\beta}_{i}\right)$, standart hataya $s\left(\hat{\beta}_{i}\right)$ bölünmesiyle elde edilir. Hesaplanan kuyruk olasılığının belirlenen anlam düzeyinden küçük olması durumunda katsayının sıfır olduğunu ileri süren sıfır hipotezi reddedilmekte böylece katsayının istatistiksel olarak anlamlı olduğu sonucuna ulaşılmaktadır.

Lojistik regresyon analizinde, katsayıların tahmininden sonraki aşama, modelin uyum iyiliğinin olup olmadığının test edilmesidir. Lojistik regresyon modelin uyum iyiliğini belirlemede kullanılabilecek yolardan biri Hosmer ve Lemeshow testidir. Test istatistiği $\chi^{2}$ dağılımına uymakta olup, test istatistiğinin $\chi^{2}$ tablo değerinden büyük olması verilerin 
modele yeterli uyumu sağlamadığını gösterirken, tam tersi durumda model uyumunun yeterli olduğu sonucuna varılmaktadır.

\section{Karar Ağaçları}

Karar ağaçları hem sınıflama hem de regresyon amacıyla kullanılan bir yöntemdir. Karar ağaçları, veriye ait sınıfların bilinmesi durumunda tümevarım yöntemiyle öğrenilen ağaç diyagramına dayalı bir karar mekanizmasına sahip tahminsel bir modeldir (Albayrak ve Yılmaz, 2009). Başka bir ifade ile karar ağaçları, bağımsız değişkenleri aşamalı olarak olası küçük gruplara bölebilen doğrusal olmayan bir ayırma metodudur. Ağaç diyagramında yer alan dallar sinıflandırma sorusunu ve yapraklar ise veri setinin bu siniflandirmaya ait parçalarını göstermektedir. Karar ağaçlarının çalışma mekanizması, iteratif algoritmalar ile bağımlı değişken üzerinde etkili olan bağımsız değişkenlerin en güçlü etkileşimini modellemek üzerine çalışmaktadır (Michael ve Gordon, 2004; Türe ve diğ., 2005).

Karar ağacı algoritmalarının diğer çok değişkenli analiz yöntemlerinde olduğu gibi normallik, varyansların homojenliği, doğrusallık gibi klasik varsayımlara sahip olmaması yöntemin en önemli avantajıdır. Karar ağaçlarının oluşturulması ve yorumlanmasından dolayı kullanışlı olması ve aynı zamanda analiz sonucunda elde edilen kuralların anlaşılır olması yöntemin tercih sebebidir. Ayrıca hem metrik hem de kategorik değişkenler için kullanılması yöntemin tercihindeki bir diğer önemli sebeptir (Saraçlı vd, 2006). Karar ağacı algoritmalar1;

a. Belirli bir sınıfa ait mümkün elemanların belirlenmesi (bölümleme),

b. Değişkenlere ilişkin kategorilerin oluşturulması (tabakalama),

c. Diğer analizlere veriyi hazırlamak amacıyla çok sayıdaki değişkenden ayırım gücü yüksek olanların tespit edilmesi,

d. Tahmin yapmak adına kurallar oluşturulması,

e. Gizli ilişki yapılarının ortaya çıkarılması,

f. Kategorilerin birleştirilmesi veya metrik değişkenin kategorik değişkene dönüştürülmesi

amaçlarıla turizm, tıp, borsa, finans, bankacılık, risk yönetimi, pazarlama gibi farklı alanlarda uygulanabilmektedir (Akpınar, 2000).

Karar ağacı modellerinde çok çeşitli algoritmalar mevcuttur. AID yöntemi ile temelleri atılan karar ağaçları zamanla geliştirilmiştir. CHAID, CART, ID3, E-CHAID, C4.5, MARS, QUEST, C5.0, SLIQ, SPRINT geliştirilen algoritmalar arasında yer almaktadır. Bu yöntemler arasında sıklıkla kullanılanı CHAID analizidir. Bunun sebepleri arasında, büyük örneklem hacmindeki veri setlerinde de kullanılabilir olması, tahminlerinin güvenilir olması, bağımsız değişkenlerdeki kayıp gözlemleri tahmin edebilmesi, ikili (binary) ve multinominal lojistik regresyon modellerine alternatif bir yöntem olarak kullanılabilmesi gösterilebilir (Doğan ve Özdamar, 2003). CHAID analizi 1980 yılında G. V. Kass tarafından oluşturulmuştur. Hem regresyon hem sınıflama amacını taşıyan bu yöntem AID yönteminin geliştirilmiş hali olup büyük veri kümelerinde de kullanılabilmektedir. CHAID yöntemi, CART yönteminin oluşturduğu ikili ağaçlarının aksine çoklu ağaçlar oluşturmaktadır (Pehlivan, 2006). CHAID algoritması aşağıda verilmektedir: 
Adım 1: Her bir bağımsız değişken $X$ için, bağımlı değişken Y'nin kategorileri ile X'in kategorileri arasında çapraz tablo oluşturulur.

Adım 2: En az öneme sahip (en büyük p değerine sahip) kategori çifti bulunur. $p$ değerleri Y'nin ölçme düzeyine göre hesaplanır.
a. Y sürekli ise $\mathrm{F}$ testini kullanılır.
b. Y nominal ise Pearson Ki-Kare testi veya olabilirlik oranı testini kullanılır.
c. Y ordinal ise birliktelik modeli oluşturulur. Olabilirlik oranı testini kullanılır.

Adım 3: En büyük $\mathrm{p}$ değerine sahip $\mathrm{X}^{\prime}$ in kategori çifti için, $\mathrm{p}$ değeri önceden belirlenmiş $\alpha$ anlam düzeyi ile kıyaslanır.
a. p değeri $\alpha$ değerinden büyük ise bu çift bir tek kategori altında birleştirilir. $X^{\prime}$ in yeni kategori kümesi için süreç Adım 1'den başlatılır.
b. p değeri $\alpha$ değerinden küçük ise Adım 4'e geçilir.

Adım 4: $\mathrm{X}$ ve Y'nin kategori kümesi için uygun Bonferroni düzeltmesini kullanarak, düzeltilmiş $\mathrm{p}$ değeri hesaplanır.

Adım 5: En küçük düzeltilmiş p değerine sahip (en önemli olan) $\mathrm{X}$ bağımsız değişkeni seçilir. p değeri önceden tanımlanmış $\alpha$ ile kıyaslanır.

a. $\quad p$ değeri, $\alpha$ değerinden küçük veya eşit ise dügüm $X^{\prime}$ in kategori kümesi temel alınarak bölünür.

b. p değeri, $\alpha$ değerinden büyük ise dügüm bölünmez. Bu düğüm uç düğüm olarak kalır.

Ağaç büyütme süreci durdurma kuralı gerçekleşinceye kadar devam eder (Kass, 1980; Koyuncugil ve Özgülbaş, 2008).

\section{Bulgular}

Çalışmada analizler SPSS 16.0 programından yararlanılarak gerçekleştirilmiştir. Öncelikli olarak ankete katılan 225 kişiye ilişkin demografik bilgiler sunulmuştur.

Tablo 1. Demografik Bilgiler

\begin{tabular}{cc|cc|cc|cc}
\hline \multicolumn{1}{c|}{ Cinsiyet } & $\mathbf{\%}$ & Yaş & $\mathbf{\%}$ & Gelir & $\mathbf{\%}$ & Eğitim & $\%$ \\
\hline Kadın & 54,2 & $19-23$ & 20,4 & -1500 & 18,2 & Lise & 2,7 \\
Erkek & 45,8 & $24-28$ & 23,6 & $1500-3000$ & 16,4 & Üniversite & 56,0 \\
& & $29-33$ & 12,9 & $3000-6000$ & 30,2 & Lisansüstü & 41,3 \\
& & $34-38$ & 16 & $6000-10000$ & 16,4 & & \\
& & $49-43$ & 7,5 & $10000+$ & 18,7 & & \\
& & $44-74$ & 19,6 & & & & \\
\hline
\end{tabular}


Tablo 1 yorumlanacak olursa, katılımcıların çoğunluğu üniversite mezunu olup, ortalama yaşı 34,5 ve gelir ortalaması 5982 TL'dir. Örneklem yüksek eğitim ve yüksek gelir düzeyine sahiptir. Ankete katılanların genel ekonomi ve finans konusundaki bilgilerine ilişkin sonuçlar Tablo 2'de özetlenmiştir.

Katılımcıların genel ekonomi ve finans konusundaki bilgileri 8 soru ile ölçülmeye çalışılmıştır. Kişilerin 8 soruya verdiği doğru cevap için 1, yanlış cevap için 0 puan verilip toplanarak her bir katılımcının puanı hesaplanmıştır. Genel ekonomi ve bilgi düzeyi ortalaması 6,81 olarak bulunmuştur. Analizin bundan sonraki kısmında Pareto prensibi gereği 8 sorudan 6 soruyu doğru cevaplayanlar "temel bilgi sahibi", daha az sayıda soruya cevap verenler ise "temel bilgi sahibi olmayanlar" şeklinde iki gruba ayrılmıştır.

Tablo 2. Genel Ekonomi ve Finans Konusundaki İfadelerin Doğru Cevaplanma Yüzdesi

\section{Doğru cevaplanma yüzdesi (\%)}

\begin{tabular}{|c|c|}
\hline Enflasyon paranın satın alma gücünü azaltır. & 98 \\
\hline Türkiye'de enflasyon oranları \%10'un altındadır. & 85 \\
\hline $\begin{array}{l}\text { Enflasyon oranı piyasadaki kredi faiz oranından yüksek ise } \\
\text { kredi kullanmak avantajlıdır. }\end{array}$ & 88 \\
\hline $\begin{array}{l}\text { Bir evi kiralamak, ev satın almaya kıyasla finansal açıdan } \\
\text { bütçenizi daha rahat kullanmanızı sağlar. }\end{array}$ & 66 \\
\hline Borsalarda sadece hisse senedi alım-satımı yapılmaktadır. & 87 \\
\hline $\begin{array}{l}\text { Türkiye'deki menkul kıymetler borsasının adı Borsa } \\
\text { İstanbul'dur. }\end{array}$ & 85 \\
\hline Vadesiz mevduat hesabı faiz kazancı sağlar. & 88 \\
\hline Ons, altın gibi kıymetli madenlerin ölçü birimidir & 93 \\
\hline
\end{tabular}

Aynı zamanda bu ayırımı desteklemek amacıyla karar ağaçlarından yararlanılmış ve sınıflandırma için doğru cevap sayısı 6,138 ve üstü olanlar "temel bilgi sahibi", diğerleri ise "temel bilgi sahibi olmayanlar" olarak iki gruba ayrılmıştır. Aşağıdaki şekilde karar ağaçları ile yapılan çözüm yer almaktadır. 


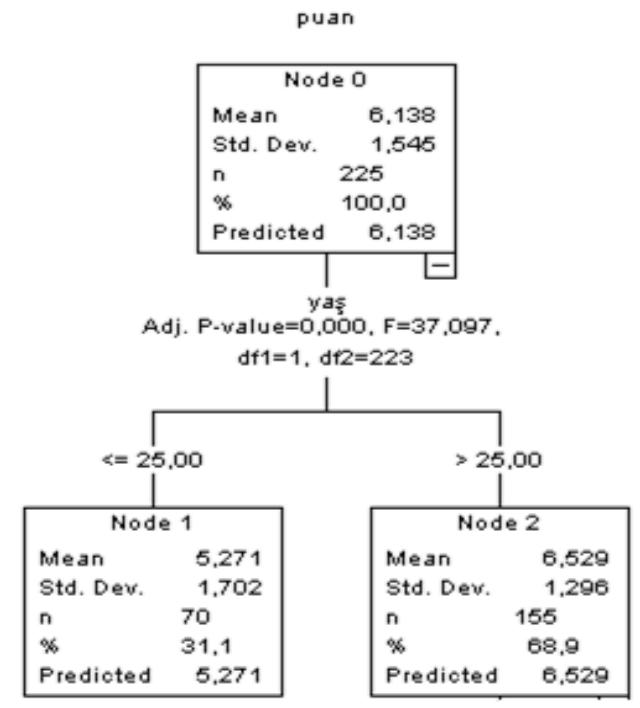

Şekil 1. Karar Ağaçları Sonucu Elde Edilen Çözüm

Şekil 1 incelendiğinde sınıflamada etkili olan değişkenlerden ilki yaştır. Yaşı 25 yaş ve daha küçük olanlar ile 25 yaş üstü olmak üzere iki gruba ayrılmıştır. Karar ağaçları ile alınan bilgi yardımıyla çalışmanın bundan sonraki kısmında gözlem iki gruba ayrılarak (25 yaş ve altı, 25 yaş üstü) analize devam edilmiştir. Çalışmanın belirlenen amacı doğrultusunda finansal okuryazarlık konusunda sosyal medya ve yazılım uygulamalarının finansal okuryazarlık üzerindeki etkisini belirlemek amacıyla lojistik regresyon analizi uygulanmıştır. "Temel bilgi sahibi", "temel bilgi sahibi olmayanlar" şeklinde oluşturulan değişken bağımlı değişken olarak ele alınmıştır. Cinsiyet, eğitim, sosyal ağ skoru, finansal davranış skoru, finansal tutum skoru ise bağımsız değişkenlerdir.

\section{a. 25 yaş üstü için lojistik regresyon analizi sonuçları}

25 yaş üstü için temel bilgi sahibi olma düzeyini etkileyebileceği düşünülen cinsiyet, eğitim, sosyal ağ skoru, finansal davranış skoru, finansal tutum skoru değişkenleri için lojistik regresyon analizi gerçekleştirilmiş ve elde edilen sonuçlar aşağıdaki tablolarda özetlenmiştir.

Tablo 3. 25 Yaş Üstü için Uyum İyiliği (Hosmer Lemeshow)

\begin{tabular}{cccc}
\multicolumn{4}{c}{ Testi Sonuçları } \\
\hline Step & Chi-square & df & Sig. \\
\hline 1 & 5,398 & 8 & 0,714 \\
\hline
\end{tabular}

Modelin uyum iyiliğinin bir ölçüsü olarak Hosmer Lemeshow testi incelendiğinde olursa \%5 anlam düzeyinde model uyumunun olduğu sonucuna ulaşılmıştır. $(p=0,714>0,05)$

Lojistik regresyon analizinde ileriye doğru adımsal seçme prosedürü uygulanmıştır. Önce sabitin yer aldığı model oluşturulmuş daha sonra modele katkısı en fazla olan değişkenden başlamak yoluyla her adımda bir değişken eklenmiştir. Sonuçta tüm değişkenlerin belirlenen anlam seviyesinde anlamlı olan değişkenler modelde tutulmuştur. Adımsal olarak değişkenler eklenerek bağımlı değişkenle anlamlı derecede ilişkili olan değişkenler belirlenerek model oluşturulmuştur. Tablo 4 incelendiğinde cinsiyet, eğitim ve sosyal ağ 
skoru değişkenlerinin istatistiksel olarak anlamlı olduğu sonucuna varılmıştır. 25 yaş üstü için eğitim seviyesi arttıkça finansal okuryazarlık temel bilgisine sahip olma olasılı̆̆ yaklaşık 4 kat artmaktadır. Bu yaş grubu için sosyal ağ skorundaki artış temel bilgi sahip olma olasılığını yükselten önemli değişkenlerden biridir.

Tablo 4. 25 Yaş Üstü için Lojistik Regresyon Sonuçları

\begin{tabular}{lcccccc}
\hline & B & S.E. & Wald & df & Sig. & $\operatorname{Exp(B)}$ \\
\hline cinsiyet(1) & 1,598 &, 454 & 12,390 & 1 &, $000^{*}$ & 4,945 \\
egitim(1) & 1,371 &, 475 & 8,314 & 1 &, $004^{*}$ & 3,939 \\
sosyalağskor &, 112 &, 062 & 3,296 & 1 &, $069^{* *}$ & 1,118 \\
Constant & $-1,388$ &, 834 & 2,773 & 1 &, 096 & \multirow{2}{*}{, 250} \\
\hline${ }^{*} 0,05{ }^{* *} 0,10$ anlam düzeyinde anlaml olan değişkenler & & \\
\hline
\end{tabular}

Cinsiyet, eğitim ve sosyal ağ skoru değişkenlerinin bağımsız değişken olarak yer aldığ lojistik regresyon analizi sonucunda doğru sınıflandırma oranı $\% 81,3$ olarak bulunmuştur.

\section{b. 25 yaş ve altı için lojistik regresyon analizi sonuçları}

25 yaş ve altı için temel bilgi sahibi olma düzeyinin bağımlı değişken cinsiyet, eğitim, sosyal ağ skoru, finansal davranış skoru, finansal tutum skoru değişkenlerinin bağımsız değişken olarak alındığı lojistik regresyon analizi sonuçları aşağıdaki tablolarda yer almaktadır.

Tablo 5. 25 Yaş ve Altı için Uyum İyiliği (Hosmer Lemeshow)

\begin{tabular}{cccc}
\multicolumn{4}{c}{ Testi Sonuçları } \\
\hline Step & Chi-square & df & Sig. \\
\hline 1 & 3,991 & 8 & 0,858
\end{tabular}

Modelin uyum iyiliğini saptamak amacıyla gerçekleştirilen Hosmer Lemeshow testi sonucunda \%5 anlam düzeyinde modelin verilere iyi uyduğu sonucuna ulaşılmıştır $(\mathrm{p}=0,858>0,05)$

Tablo 6. 25 Yaş ve Altı için Lojistik Regresyon Sonuçları

\begin{tabular}{|c|c|c|c|c|c|c|}
\hline & B & S.E. & Wald & df & Sig. & $\operatorname{Exp}(B)$ \\
\hline finansaltutum & 1,598 & 454 & 12,390 & 1 &, $000^{*}$ & 4,945 \\
\hline Constant & $-1,388$ & 834 & 2,773 & 1 & 096 & 250 \\
\hline
\end{tabular}

Analizin başında belirlenen bağımsız değişkenlerden anlamlı olanların yer aldığı model Tablo 6' da gösterilmiştir. Buna göre 25 yaş ve altı için finansal okuryazarlıkla ilgili temel bilgi düzeyini etkileyen değişken kişilerin finansal okuryazarlık tutum skorlarıdır. Oluşturulan modelle doğru sınıflandırma yüzdesi \%64,3 olarak bulunmuştur. 


\section{Sonuç}

Türkiye'de nüfusun yaklaşık \%10'unun servetin \%90'ına sahip olduğu gerçeği ile bakıldığında çoğu birey için kısıtlı gelirleri ile geçinme kaygısı bulunmaktadır. Finans, büyük bir kısım için çevresinden borç alıp, çeşitli kaynaklardan elde ettiği gelir ile bu borcu kapamaktır. Bir başka gerçek ise farklı kredi kaynakları ile tüketim yaparak bunları birbirleri ile dengelemeye çalışmak finans olarak görülmektedir. Dolayısı ile finansman büyük bir kesim için bir uzmanlık alanı ve meslek olarak algılanmaktadır. Genç nesil değerlendirildiğinde ilgi alanları çok farklı olup, daha çok anı yaşamaya dayalı bir yaklaşımları olduğu görülmektedir. Aralarında özellikle eğitimli kesimde finans kariyeri hedefleyenler olup, bu yönde tutum gerçekleştirenler konu hakkında bilgi sahibi olmaktadırlar.

Diğer taraftan 25 yaş üstü genelde iş bulan ve çalışmaya başlayan kesim, ki örneklemde bu sınıf da oldukça gençtir ve internet kullanımına aşinadır, gelirlerini arttırmak için alternatif arayışı ile sosyal ağları takip ederek birikimlerini kısmen finansal araçlar ile değerlendirmeye çalışmaktadırlar.

Mevcut araştırmalarda finansal okuryazarlık ile gelir veya varlık ilişkisi hakkında yapılan çalışmalara pek fazla rastlanmamıştır. Belirli bir gelir seviyesi olmayan bireyler için finansal okuryazarlık sadece kendi gelirleri ile ilgiliymiş gibi algılanıp, makro ekonomik göstergelere de ihtiyaç duyulmamakta ve onları bir ihtimal politik işaretler olarak algılamaktadırlar. Eğitimin etkili bir gösterge olmasının sebebi aynı zamanda gelirin bir öncü göstergesi olması ve diğer taraftan eğitim toplumsal sorunlara olan ilgiyi arttırarak ekonomik durumun takibini de birlikte getirmesidir.

Literatür incelendiğinde yapılan analizlerde yaşa göre ayırım yapılmadan analizlerin gerçekleştirildiği görülmektedir. Yapılan bu çalışma yardımıyla, katılımcıların genel ekonomi ve finans konusundaki bilgi düzeylerinin sınıflanmasında yaşın önemli bir faktör olduğu belirlenerek, analizler 25 yaş üstü ve 25 yaş ve altı olmak ikiye ayrılarak yapılmış; iki yaş grubu için bulunan sonuçlarda farklı değişkenlerin öneme sahip olduğu saptanmıştır. Aynı zamanda diğer çalışmalaradan farklı olarak sosyal ağ kullanımı ile finansal okuryazarlık durumları arasındaki ilişkiyi ortaya koyulmuştur. Finansal okuryazarlık konusunda bundan sonra yapılacak olan çalışmalarda sosyal ağ ve etkileşimlerinin de ölçülmesi, sosyal medyanın finansal okuryazarlığı nasıl değiştirdiği, temel ve ileri finansal okuryazarlıkta sosyal medya kaynaklarının öneminin incelenmesi yararlı olacaktır.

\section{Kaynakça}

Akpınar, H.(2000). Veri Tabanlarında Bilgi Keşfi ve Veri Madenciliği, İstanbul Üniversitesi İsletme Fakültesi Dergisi, 29: 1-22.

Albayrak, A. S., \& Yılmaz, Ş. K. (2009). Veri Madenciliği: Karar Ağacı Algoritmaları ve İMKB Verileri Üzerine Bir Uygulama, Süleyman Demirel Üniversitesi İktisadi ve İdari Bilimler Fakültesi Dergisi, 14(1), 31-52.

Alkaya, A., \& Yağlı, İ. (2015). Finansal Okuryazarlık-Finansal Bilgi, Davranış Ve Tutum: Nevşehir Hacı Bektaş Veli Üniversitesi İİB Öğrencileri Üzerine Bir Uygulama, Journal of International Social Research, 8(40). 585-599. 
Atkinson, A., \& Messy, F. (2012). Measuring Financial Literacy: Results of the OECD / International Network on Financial Education (INFE) Pilot Study.

Barış, S. (2016). Finansal Okuryazarlık ve Bütçeleme Davranışı: Üniversite Öğrencileri Üzerine Bir Araştırma, TESAM Akademi Dergisi, 3(2), 13-38.

Bayar, Y., Sezgin, H. F., Öztürk, Ö. F., \& Şaşmaz, M. (2017). Impact of Financial Literacy On Personal Savings: A Research On Usak University Staff, Journal of Knowledge Management Economics and Information Technology, VII (6), December, 1-19.

Biçer, E. (2016). Üniversite Öğrencilerinin Finansal Okuryazarlık ile İlgili Tutum ve Davranışlarının Değerlendirilmesi, Atatürk Üniversitesi Sosyal Bilimler Enstitüsü Dergisi, 20 (4), 1519-1533.

Çetiner, M., \& Çilingirtürk, A. M. (2019). Sosyal Ağların Finansal Okuryazarlık Üzerine Etkisi, Sosyoekonomi, 27(41), 41-56.

Çinko, M., Avcı, E., Ergun, S., \& Tekçe, M. (2017). Üniversite öğrencilerinin finansal okuryazarlık düzeyleri: Marmara Üniversitesi örneği, Marmara Business Review, 2(1), 2550.

Doğan, N., \& Özdamar, K. (2003). CHAID Analizi Ve Aile Planlaması İle İlgili Bir Uygulama, Turkiye Klinikleri Journal of Medical Sciences, 23(5), 392-397.

FODER, (2017). Finansal Okur-yazarlık Araştırması, https://www.fo-der.org/foder-visaturkiye-1-finansal-okuryazarlik-arastirmasi/ (12.07.2019)

Durmuşkaya, S., \& Kavas, Y. B. (2018). Akademik Gelişim Ve Finansal Okuryazarlık Arasındaki İlişkinin Tespiti Üzerine Bir Araştırma, Yönetim ve Ekonomi, 25(3), 925.

Greenspan, A. (2002). Financial Literacy: A Tool for Economic Progress, The Futurist, 36, (4) : 37-41.

Güngör Karyağdı, N. (2018). Finansal Okuryazarlık ve Farkındalığının Belirlenmesine Yönelik Bitlis Eren Üniversitesi SBMYO Öğrencileri Üzerine Bir Uygulama, İşletme Ekonomi ve Yönetim Araştırmaları Dergisi, 1 (2), 110-126.

Hosmer Jr, D. W., Lemeshow, S., \& Sturdivant, R. X. (2013). Applied logistic regression (Vol. 398). John Wiley \& Sons.

IBM, SPSS. https://www.ibm.com/tr-tr/analytics/spss-statistics-software

Kass, G. V. (1980). An Exploratory Technique for Investigating Large Quantities of Categorical Data, Journal of the Royal Statistical Society: Series C (Applied Statistics), 29(2), 119-127.

Kılıç, Y., Ata, H.A. \& Seyrek, İ. H. (2015), Finansal Okuryazarlık: Üniversite Öğrencilerine Yönelik Bir Araştırma, Muhasebe ve Finansman Dergisi, (66), 129-150. 
Koyuncugil, A. S., \& Özgülbaş, N. (2008). IMKB'de İşlem Gören KOBİ'lerin Güçlü ve Zayıf Yönleri: CHAID Karar Ağacı Uygulaması, Dokuz Eylül Üniversitesi İktisadi İdari Bilimler Fakültesi Dergisi, 23(1), 1-21.

Michael, J. A., \& Gordon, S. L. (1997). Data mining technique for marketing, sales and customer support. New York: Wiley.

OECD INFE (2011). Measuring Financial Literacy: Questionnaire and Guidance Notes for Conducting an Internationally Comparable Survey of Financial Literacy. Organisation for Economic Co-operation and Development: Paris.

Pehlivan, G. (2006). CHAID Analizi ve Bir Uygulama. Yayınlanmamış Yüksek Lisans Tezi. İstanbul: Yıldız Teknik Üniversitesi, FBE.

Saraçlı, S., Doğan, İ., Kaygısız, Z. \& Kaya, M. (2006). Osmangazi Üniversitesi İ.İ.B.F. Öğrencilerinin Bölüm Değiştirmeyi İsteyip İstemediklerinin İncelenmesi, Eğitim Araştırmaları Dergisi, 22: 179-187.

Sarıgül, H. (2015), Finansal Okuryazarlık Tutum ve Davranış Ölçeği: Geliştirme Geçerlik ve Güvenirlik, Yönetim ve Ekonomi Araştırmaları Dergisi, 13(1), 200-218.

Şahin, M \& Barış, S. (2017). Finansal Okuryazarlık ve Tasarruf Davranışları: Kamu Çalışanları Üzerine Bir İnceleme, Çankırı Karatekin Üniversitesi İ̈BF Dergisi, 7 (2), 77-103.

Tatlıdil, H. (2002). Uygulamalı Çok Degişkenli İstatistiksel Analiz., Ankara :Ziraat Matbaacilik, 2002.

Türe, M., Kurt, İ., Kurum, At. \& Özdamar, K. (2005). Comparing Classification Techniques for Predicting Essential Hypertension, Expert Systems with Applications, 29, 583-8.

Wachira, M. I. \& Kihiu, E. N. (2012). Impact of Financial Literacy on Access to Financial Services in Kenya, International Journal of Business and Social Science, Vol. 3, No. 19, pp. $42-$ 50.

\section{Açıklamalar}

Pareto prensibi: Hayattaki pek çok şeyin denk ve eşit dağılmadığı gözlemine dayanan Vilfredo Pareto'ya ait bir prensip olup, sonuçların \%80'inin kaynağının sebeplerin \%20'sinden oluştuğunu kabul eder. Daha çok konsantrasyon katsayılarında kullanılan Pareto dağılımı küçük bir nesnenin büyük bir nesneye dağılımındaki kararlılığı temsil eden ve güç kuramına dayalı sürekli bir olasılık dağılımıdır. 